\title{
CARDIAC SURGERY IN A HIGH-RISK GROUP OF PATIENTS: IS PROLONGED POSTOPERATIVE ANTIBIOTIC PROPHYLAXIS EFFECTIVE?
}

Urs Niederhäuser, MD

Markus Vogt, $\mathrm{MD}^{\mathrm{a}}$

Paul Vogt, MD

Michele Genoni, MD

Andreas Künzli, MD

Marko I. Turina, MD
Objective: In a prospective, randomized study, postoperatively prolonged antibiotic prophylaxis is evaluated in a high-risk group of patients undergoing cardiac operations. These patients had postoperative low cardiac output necessitating inotropic support and intraaortic balloon pumping. Methods: Between January 1991 and 1994, 53 patients were enrolled in the study (42 men, mean age 65 years). All patients received the usual perioperative ( 24 hours) cefazolin prophylaxis. In the study group $(n=28)$ a prolonged regimen of prophylaxis with ticarcillin/clavulanate was performed for 2 days and vancomycin was added in a low dose until removal of the intraaortic balloon pump. The control group $(n=25)$ did not receive a prolonged regimen of prophylaxis. Follow-up ended at hospital discharge. Results: Early mortality was 7 of 28 patients (25\%) in the prophylaxis group and 8 of 25 patients $(32 \%)$ in the control group $(p=0.397)$. Defined infections (pneumonia, $n=22$; sepsis, $n=8$; deep sternal wound infection, $n=2$ ) occurred in $50 \%$ of the study group and $68 \%$ of the control group $(p=0.265)$. In all patients with septicemia, only coagulase-negative staphylococci could be isolated from the bloodstream ( 5 patients in the prophylaxis group vs 3 in the control group). Infectious parameters were controlled daily and did not differ significantly between groups. A total of 1158 bacteriologic tests were performed (blood cultures, $n=389$; intravascular catheters, $n=208$; bronchial aspirates, $n=411$; intraaortic balloon pumps, $n=42$; wound secretions, $n=108$ ) showing bacterial growth in 322 (28\%) without a significant difference between the groups. In the prophylaxis group, 13 intravascular catheters and intraaortic balloon pumps showed bacterial growth versus 11 in the control group. No side effects were seen. Conclusion: In a high-risk group of patients undergoing cardiac operations, infectious outcome could not be effectively influenced by an additional and prolonged postoperative prophylaxis regimen with low-dose vancomycin and ticarcillin/clavulanate. Low-dose vancomycin did not reduce the rate of infections or colonizations of intravascular catheters with gram-positive organisms. (J Thorac Cardiovasc Surg 1997;114:162-8)
A ntibiotic prophylaxis has been performed routinely in cardiac surgery since Geraci, Dale, and McGoon $^{1}$ in 1963 reported about a $10 \%$ incidence

From the Clinic for Cardiovascular Surgery, University Hospital Zürich and City Hospital Triemli, Zürich; and the Division for Infectious Disease Department of Medicine, ${ }^{\text {a University Hos- }}$ pital Zürich, Zürich, Switzerland.

Received for publication August 8, 1996; revisions requested Dec. 31, 1996; revisions received April 14, 1997; accepted for publication April 16, 1997.

Address for reprints: Urs Niederhäuser, MD, Clinic for Cardiovascular Surgery, City Hospital Triemli, CH-8063 Zürich, Switzerland.

Copyright (C) 1997 by Mosby-Year Book, Inc.

$0022-5223 / 97 \$ 5.00+0 \quad \mathbf{1 2 / 1 / 8 2 6 7 0}$ of prosthetic valve endocarditis with staphylococci. In placebo groups of prospective, randomized studies, wound infection rates even ranged from $9.1 \%$ to $54.5 \%{ }^{2}$ In the meantime, the benefit of a short (mostly 24 hours) perioperative prophylaxis regimen has been confirmed by several authors. ${ }^{2-5}$ Long-term prophylaxis could not be demonstrated $d^{6-9}$ to be efficacious in patients who were undergoing cardiac operations and who did not have high risk factors. In long-term prophylaxis, principal target organisms have been coagulase-negative staphylococci (CNS) associated with nosocomial infections and endocarditis.

In a prospective, randomized study we have eval- 
uated postoperatively prolonged antibiotic prophylaxis in a high-risk group of patients undergoing cardiac operations. The working hypothesis was that prolonged administration of antibiotics can prevent or reduce infectious complications. Currently the literature contains no reports about reduction of nosocomial infections by postoperatively extended application of antibiotics in such a subgroup of patients.

\section{Patients and methods}

Patients with severe heart failure who could not be weaned from cardiopulmonary bypass without intraaortic balloon pumping (IABP) were included in the study.

Immediately after the operation the patients receiving IABP support were randomized into two groups according to a randomization list. All patients received the usual perioperative intravenous antibiotic prophylaxis with $3 \mathrm{gm}$ of cefazolin in 24 hours. The first dose of $1 \mathrm{gm}$ was given at induction of anesthesia, the second dose (1 gm) after 8 hours, and the third dose (1 gm) after another interval of 8 hours. Patients of the study group (prophylaxis group) were subjected to a prolonged regimen of antibiotic prophylaxis that started after completion of the cefazolin prophylaxis. The protocol was as follows: Ticarcillin/ clavulanate (Timenten, SmithKline Beecham AG) was administered as a short-term intravenous infusion. The dose of $5.2 \mathrm{gm}$ was administered every 8 hours for 2 days. Additionally, vancomycin was administered in a low intravenous dosage of $500 \mathrm{mg}$ every 12 hours until removal of the IABP. Patients in the control group received the normal perioperative cefazolin prophylaxis for 24 hours but not the prolonged prophylaxis. Patients with preexisting infections necessitating antibiotic treatment and patients with an allergy to betalactam antibiotics or vancomycin were excluded from the study.

Definitions. All patients were evaluated daily for infection until the end of the hospitalization. The following infections were defined according to the definitions of the Centers for Disease Control and Prevention ${ }^{10}$ : Wound infection indicates incisional wound infections involving the skin, subcutaneous tissue, or muscle above the fascial layer with purulent drainage from the incision or bacterial growth from wounds that are primarily closed. Deep surgical wound infections involve tissues beneath the fascial layer with purulent drainage from deeply placed drains, with spontaneous dehiscences or purulent and culture-positive secretion after surgical opening. An abscess or other evidence of infection can be seen on direct examination, during the operation, or by histopathologic examination. Pneumonia is defined as purulent and culture-positive bronchial or tracheal secretion (obtained by transtracheal aspiration, bronchial brushing, or biopsy) in the presence of clinical and radiologic signs suggestive of pneumonia. Two types of bloodstream infection were identified. Primary bloodstream infection includes isolation of a pathogen in a blood culture and clinical sepsis. If an organism is related to a nosocomial infection at another site, the bloodstream infection is classified as secondary. Catheter infection (more than five colonies on the agar plate rolled over by the tip of the catheter) is distinguished from contamination by means of a semiquantitative technique. $^{11}$

Bacteriology/laboratory findings. The following examinations were routinely performed in all patients: (1) bacteriologic examination of a wound swab, with an open thorax at each change of wound dressing; (2) bacteriologic examination of all intravascular catheters and the IABP catheter; (3) bacteriologic examination of tracheal secretions at least once per day until extubation (Gram stain/ culture); (4) three blood cultures (aerobic and anaerobic) before the start of prolonged prophylaxis; (5) three blood cultures when the body temperature was more than $38.5^{\circ} \mathrm{C}$.

Daily laboratory studies included the following: hemoglobin concentration, hematocrit value, white blood cell count, platelet count, phosphate, C-reactive protein, creatinine, creatinine clearance on the first postoperative day, and daily body temperature. Chest roentgenograms were obtained daily during the patients' stay in the intensive care unit.

Between January 1991 and January 1994, cardiac operations with the heart-lung machine were performed in 2152 adult patients at the Clinic for Cardiovascular Surgery of the University Hospital and the City Hospital Triemli of Zürich. Of this series, $53(2.4 \%)$ consecutive patients ( $42 \mathrm{men}$ ) were included in the study, which was approved by the ethics committee and the institutional review board of the hospital. Informed consent was obtained from the patients or their legal representatives. All patients had severely reduced left ventricular function with low cardiac output syndrome and with the need for inotropic support and IABP to be weaned from cardiopulmonary bypass. The study group (receiving additional vancomycin/ticarcillin prophylaxis) comprised 28 patients (25 men) and the control group (receiving only the short perioperative cefazolin prophylaxis), 25 patients $(17 \mathrm{men})$. The difference in sex between the two groups approached statistical significance $(p=0.058)$. Mean age was 64.7 years $\left(\mathrm{SD}^{*} 9.5\right.$ years, minimum 35 years, maximum 83 years) and was not significantly different in the two groups $(p=0.605)$. The following operations were performed: coronary artery bypass grafting (CABG), 33; CABG and left ventricular aneurysmectomy, 2; CABG and valve replacement, 11 (mitral 5, aortic 6); mitral valve replacement, 2; aortic valve replacement, $1 ; \mathrm{CABG}$ and double valve replacement, 2; CABG and ventricular septal defect closure, 1; and postinfarction ventricular septal defect closure, 1. Because of an extremely unstable hemodynamic situation, the sternotomy could not be closed in 18 patients (11 in the prophylaxis group and 7 in the control group; $p=0.283$ ). Mean durations of IABP and open chest were 109.8 hours (SD 125.6 hours; minimum 6 hours; maximum 840 hours) and 61.7 hours (SD 66.2 hours; minimum 6 hours; maximum 288 hours), respectively, without a statistically significant difference between the two groups. During the study period $2.6 \%$ of the patients needed IABP support.

Follow-up. The mean follow-up period among surviving patients was 53.47 days (SD 99.7 days; minimum 3

\footnotetext{
${ }^{*} \mathrm{SD}=$ Standard deviation
} 
Table I. Type of infection

\begin{tabular}{|c|c|c|c|c|c|}
\hline \multirow{2}{*}{$\begin{array}{c}\text { Type of } \\
\text { infection }\end{array}$} & \multicolumn{2}{|c|}{$\begin{array}{l}\text { Prophylaxis } \\
\text { group }\end{array}$} & \multicolumn{2}{|c|}{ Control group } & \multirow{2}{*}{$\begin{array}{c}p \\
\text { Value } \\
\end{array}$} \\
\hline & No. & $\%$ & No. & $\%$ & \\
\hline Pneumonia & 9 & 32 & 13 & 52 & NS \\
\hline Sepsis & 5 & 18 & 3 & 12 & NS \\
\hline Sternal wound & 1 & 4 & 1 & 4 & NS \\
\hline Total & 15 & & 17 & & NS \\
\hline
\end{tabular}

NS, Not significant.

Table II. Type of pathogen

\begin{tabular}{lccc}
\cline { 1 - 2 } Type of organism & $\begin{array}{c}\text { Prophylaxis } \\
\text { group } \\
(\text { No. })\end{array}$ & $\begin{array}{c}\text { Control } \\
\text { group } \\
(\text { No. })\end{array}$ & $\begin{array}{c}p \\
\text { Value }\end{array}$ \\
\hline Gram-negative & 11 & 17 & NS \\
Gram-positive & 9 & 15 & NS \\
Gram-negative + & 7 & 12 & NS \\
$\quad$ gram-positive & & & \\
Multiple organisms $(>2)$ & 10 & 17 & NS \\
CNS & 8 & 12 & NS \\
Candida & 12 & 14 & NS \\
\hline
\end{tabular}

CNS, Coagulase-negative staphylococci; NS, not significant.

days; maximum 540 days). Hospital deaths and late deaths were defined according to published guidelines of The American Association for Thoracic Surgery. ${ }^{12}$

Statistical methods. We used Fisher's exact text to determine significance for discrete variables. Continuous variables were analyzed by a Mann-Whitney test. The relative risk was calculated by the statistical program EPED. ${ }^{13}$

\section{Results}

No patient in either group had to be excluded from the study.

Early mortality. Total early mortality was 15 of 53 patients $(28.3 \%)$. In the prophylaxis group early mortality was 7 of 28 patients $(25 \%)$ and in the control group 8 of 25 patients (32\%). Differences between the two groups were not statistically significant $(p=0.397)$. Death occurred in the early postoperative period after a mean interval of 8.3 days. In the study group, cause of death was cardiogenic in 3 patients (low cardiac output, 2; arrhythmia, 1), related to sepsis with multiorgan failure in 3 patients, and of cerebral origin in 1 patient. In the control group, the cause was low output in 5 and sepsis in 3 patients.

Infections. Postoperative infections (Table I) occurred in 15 of 28 patients $(53.6 \%)$ in the study group (95\% confidence interval $=53.9 \%$ to $72.5 \%$ ) and in 17 of 25 patients (68\%) in the control group
Table III. Isolated pathogens in patients with clinical and radiologic signs of pneumonia

\begin{tabular}{lcc}
\hline & $\begin{array}{c}\text { Prophylaxis } \\
\text { group } \\
\text { (No.) }\end{array}$ & $\begin{array}{c}\text { Control } \\
\text { group } \\
\text { (No.) }\end{array}$ \\
\hline Serratia & 1 & 1 \\
Proteus & 1 & 2 \\
Enterobacter & 3 & 1 \\
Haemophilus influenzae & 2 & 5 \\
Klebsiella & 1 & 3 \\
Pseudomonas & 0 & 2 \\
Escherichia coli & 0 & 2 \\
Citrobacter & 0 & 1 \\
Enterococci & 1 & 0 \\
Staphylococcus aureus & 1 & 0 \\
Streptococcus pneumoniae & 1 & 2 \\
Hemolytic streptococci & 1 & 0 \\
\hline
\end{tabular}

( $95 \%$ confidence interval $46.5 \%$ to $85.0 \%$ ), without a statistically significant difference between groups $(p=0.265)$. The relative risk for infection was 1.27 (95\% confidence limits 0.82 to 1.97 ) and, measured by the odds ratio, 1.84 ( $95 \%$ confidence limits 0.53 to 6.6) for the control group versus the study group. Sepsis occurred in 5 patients $(18 \%)$ of the study group and in 3 patients $(12 \%)$ of the control group $(p=0.708)$, with a relative risk of $0.93(95 \%$ confidence interval 0.75 to 1.17 ) and an odds ratio of 0.63 ( $95 \%$ confidence interval 0.09 to 3.71 ) for the control group versus the study group. The type of pathogens cultivated in both groups is indicated in Table II. The different pathogens isolated in tracheal or bronchial aspirations from patients with pneumonia are indicated in Table III. Gram-negative organisms accounted for the majority of isolates in both groups. In all patients with sepsis, only CNS could be isolated from the bloodstream: in the prophylaxis group, 1 blood culture, 2 intravascular catheters, and 2 IABPs; in the control group, 1 intravascular catheter and 2 IABPs. The following organisms could be isolated (prophylaxis group/ control group): blood culture: CNS, 2/3; Enterobacter agglomerans, 0/1; Streptococcus mitis, 0/1; intravascular catheters: CNS, 7/8; Enterococcus, 2/0; Enterobacter cloacae, 0/1; Serratia, 0/1; IABPs: CNS, $5 / 3$. In the prophylaxis group growth of CNS was found on all culture-positive IABPs (5/5) and on 7 of 8 culture-positive intravascular catheters. In the control group CNS was found on all culture-positive intravascular catheters (8/8) and IABPs (3/3). Candida was found in bacteriologic cultures in 12 patients of the prophylaxis group (43\%) and in 14 
patients of the control group (56\%). Tracheal secretion was responsible for $88 \%$ of all positive cultures.

Antibiotic therapy. Because of new-onset infection or changes of floral composition or resistance spectrum, antibiotic therapy was instituted in 15 of 28 patients (14 combination therapies, 1 single-drug therapy) in the prophylaxis group and in 20 of 25 patients (19 combination therapies, 1 single-drug therapy) in the control group ( $p=0.08$ ).

Laboratory data. Laboratory data and results of bacteriologic tests are depicted in Tables IV and V. The minimum body temperature was significantly lower in the control group $(p=0.019)$, and the minimum platelet count was also lower in the control group $(p=0.030)$. The other laboratory values did not differ significantly between groups. Serum levels of vancomycin were measured in 13 patients: mean value for the peak level was $28.6 \mu \mathrm{g} / \mathrm{ml}$ (SD, $3.0 \mu \mathrm{g} / \mathrm{ml}$; minimum, $13.3 \mu \mathrm{g} / \mathrm{ml}$; maximum, 50.4 $\mu \mathrm{g} / \mathrm{ml}$ ) and for the trough level $8.2 \mu \mathrm{g} / \mathrm{ml}$ (SD, 6.0 $\mu \mathrm{g} / \mathrm{ml}$; minimum, $3.8 \mu \mathrm{g} / \mathrm{ml}$; maximum, $26.0 \mu \mathrm{g} / \mathrm{ml})$. In both groups a total of 1158 bacteriologic tests were performed (blood cultures, 389; intravascular catheters, 208; tracheal secretions, 411; tips of IABPs, 42; wound swabs, 108). The number of microbiologic tests with (positive) or without (negative) bacterial growth did not differ significantly in the two groups (Table V). There was also no significant difference in the number of patients with positive or negative bacteriologic results (Table VI).

\section{Discussion}

In this prospective, randomized study including only a high-risk group of patients having cardiac operations (low cardiac output, IABP), infectious outcome could not be effectively influenced by a postoperatively prolonged regimen of antibiotic prophylaxis compared with normal short-term prophylaxis. For a number of reasons the study patients were at increased risk for infections: With the percutaneously implanted IABP and the intraarterial pump line, a large amount of intravascular foreign material remained in place, usually for a long time. The interruption of the skin barrier by percutaneously implanted devices and catheters may predispose to local infection at the site of entry or exit. Common skin pathogens like CNS or Staphylococcus aureus may colonize along the catheter tract, producing thrombophlebitis and sepsis. ${ }^{14}$ Staphylococcus epidermidis is most frequently responsible for infections around foreign material. Nosocomial bacteremias are mostly caused by CNS
Table IV. Laboratory parameters

\begin{tabular}{|c|c|c|c|c|c|}
\hline \multirow[b]{2}{*}{ Laboratory parameters } & \multicolumn{2}{|c|}{$\begin{array}{l}\text { Prophylaxis } \\
\text { group }\end{array}$} & \multicolumn{2}{|c|}{$\begin{array}{l}\text { Control } \\
\text { group }\end{array}$} & \multirow[b]{2}{*}{$\begin{array}{c}p \\
\text { Value }\end{array}$} \\
\hline & $\begin{array}{l}\text { Mean } \\
\text { value }\end{array}$ & $\pm S D$ & $\begin{array}{l}\text { Mean } \\
\text { value }\end{array}$ & $\pm S D$ & \\
\hline Hematocrit (\%), Min. & 29.5 & 3.2 & 29.1 & 3.1 & NS \\
\hline WBC $\left(\times 10^{3}\right)$, Max. & 15.3 & 7.4 & 15.4 & 7.4 & NS \\
\hline WBC diff., Max. & 47.2 & 10.9 & 44.4 & 14.8 & NS \\
\hline \multicolumn{6}{|l|}{ Platelets $\left(\times 10^{3}\right)$} \\
\hline Max. & 154.5 & 64.2 & 173.0 & 133.5 & NS \\
\hline Min. & 75.4 & 31.9 & 60.1 & 23.0 & 0.06 \\
\hline \multicolumn{6}{|l|}{ Phosphate $(\mathrm{mmol} / \mathrm{L})$} \\
\hline Max. & 1.22 & 0.47 & 1.29 & 0.51 & NS \\
\hline Min. & 0.53 & 0.48 & 0.59 & 0.28 & NS \\
\hline \multicolumn{6}{|l|}{ CRP (mg/L) } \\
\hline Max. & 227.3 & 98.8 & 205.3 & 81.3 & NS \\
\hline Min. & 58.9 & 35.0 & 68.1 & 46.1 & NS \\
\hline \multicolumn{6}{|l|}{ Creatinine $(\mu \mathrm{mol} / \mathrm{L})$} \\
\hline Max. & 231 & 121 & 230 & 117 & \\
\hline Min. & 121 & 39 & 137 & 64 & NS \\
\hline Creat. clearance $(\mathrm{ml} / \mathrm{min})$ & 61 & 42 & 45.4 & 34 & NS \\
\hline \multicolumn{6}{|l|}{ Temperature $\left({ }^{\circ} \mathrm{C}\right)$} \\
\hline Max. & 38.5 & 0.8 & 38.1 & 1.1 & NS \\
\hline Min. & 36.9 & 1.0 & 36.5 & 0.7 & 0.019 \\
\hline
\end{tabular}

Minimum (Min.) and maximum (Max.) values are indicated. Creat. clearance, Creatinine clearance; $C R P$, c-reactive protein; $S D$, standard deviation; NS, not significant; $W B C$ diff, white blood cell differentiation.

and have a mortality of up to $30 \% \cdot{ }^{15-17}$ In addition, a prolonged period of low cardiac output can also be detrimental to the immune system. Hillis and associates $^{8}$ reported a $27 \%$ incidence of infection in a subgroup of patients with low cardiac output and prolonged antibiotic prophylaxis compared with an incidence of $3.5 \%$ to $5.1 \%$ in patients without low output. Additionally, closure of the thorax and tracheal extubation are often delayed in patients receiving inotropic and IABP support, and their stay in the intensive care unit is extended. The prolonged prophylaxis was performed with low-dose vancomycin and ticarcillin/clavulanate. Vancomycin is the prefered antibiotic against methicillin-resistant staphylococci. ${ }^{18-20}$ In our hospital the rate of methicillin resistance is 3\% for Staphylococcus aureus and $40 \%$ for CNS. ${ }^{21}$ The sensitivity of both pathogens to vancomycin is $100 \%$. With the low dosage, adverse effects of vancomycin, especially renal toxicity and hemodynamic impairment, ${ }^{22,23}$ are minimized. In a prospective study, Karp and Dick ${ }^{24}$ demonstrated the efficacy of low-dose vancomycin $(500 \mathrm{mg}$ twice daily) in the prevention of breakthrough grampositive infections in patients with aplastic leukemia. In the presented study, all patients with prolonged prophylaxis had low-dose vancomycin during a vari- 
Table V. Bacteriology: Number of microbiologic tests showing bacterial growth

\begin{tabular}{|c|c|c|c|c|c|c|c|c|}
\hline \multirow{2}{*}{$\frac{\text { Bacteriology }}{\text { Blood }}$} & \multirow{2}{*}{$\begin{array}{c}\text { No. } \\
389\end{array}$} & \multirow{2}{*}{$\frac{\text { Positive }}{12}$} & \multirow{2}{*}{$\frac{\%}{3.0}$} & \multicolumn{2}{|c|}{ Prophylaxis group } & \multicolumn{2}{|c|}{ Control group } & \multirow{2}{*}{$\frac{p \text { Value }}{\text { NS }}$} \\
\hline & & & & Pos. & 5 & Pos. & 7 & \\
\hline & & & & Neg. & 204 & Neg. & 173 & \\
\hline \multirow{2}{*}{$\begin{array}{l}\text { Intravascular } \\
\text { catheters }\end{array}$} & 208 & 28 & 13.5 & Pos. & 13 & Pos. & 15 & NS \\
\hline & & & & Neg. & 98 & Neg. & 82 & \\
\hline \multirow{2}{*}{$\begin{array}{l}\text { Bronchial } \\
\text { secretions }\end{array}$} & 411 & 265 & 64.5 & Pos. & 142 & Pos. & 123 & NS \\
\hline & & & & Neg. & 101 & Neg. & 45 & \\
\hline \multirow[t]{2}{*}{ IABP } & 42 & 8 & 19 & Pos. & 5 & Pos. & 3 & NS \\
\hline & & & & Neg. & 17 & Neg. & 17 & \\
\hline \multirow[t]{2}{*}{ Wound } & 108 & 9 & 8.3 & Pos. & 2 & Pos. & 7 & NS \\
\hline & & & & Neg. & 67 & Neg. & 32 & \\
\hline \multirow[t]{2}{*}{ Total } & 1158 & 322 & 27.8 & Pos. & 167 & Pos. & 155 & NS \\
\hline & & & & Neg. & 487 & Neg. & 349 & \\
\hline
\end{tabular}

$\overline{L A B P}$, Intraaortic balloon pump; $N S$, not significant.

Table VI. Number of patients with positive or negative bacteriologic results

\begin{tabular}{|c|c|c|c|c|c|}
\hline $\begin{array}{l}\text { Cultured } \\
\text { material }\end{array}$ & Bacteriology & No. of patients & $\begin{array}{l}\text { Prophylaxis } \\
\text { group }\end{array}$ & $\begin{array}{l}\text { Control } \\
\text { group }\end{array}$ & $p$ Value \\
\hline \multirow[t]{2}{*}{ Blood } & Positive & 7 & 2 & 5 & NS \\
\hline & Negative & 40 & 24 & 16 & \\
\hline \multirow{2}{*}{$\begin{array}{l}\text { Intravascular } \\
\text { catheters }\end{array}$} & Positive & 16 & 8 & 8 & NS \\
\hline & Negative & 27 & 14 & 13 & \\
\hline \multirow{2}{*}{$\begin{array}{l}\text { Tracheal } \\
\text { secretion }\end{array}$} & Positive & 43 & 22 & 21 & NS \\
\hline & Negative & 7 & 6 & 1 & \\
\hline \multirow[t]{2}{*}{ IABP } & Positive & 8 & 5 & 3 & NS \\
\hline & Negative & 33 & 17 & 16 & \\
\hline \multirow[t]{2}{*}{ Wound } & Positive & 6 & 2 & 4 & NS \\
\hline & Negative & 15 & 10 & 5 & \\
\hline
\end{tabular}

$L A B P$, Intraaortic balloon pump; $N S$, not significant.

able length of time (duration of IABP); the therapy was principally aimed at reducing catheter-related gram-positive infections. The trough serum levels were measured in 13 patients and they were well above $2 \mu \mathrm{g} / \mathrm{ml}$ (minimum, $3.8 \mu \mathrm{g} / \mathrm{ml}$ ) in all cases. Ticarcillin, on the other hand, is active against $\beta$-lactamase-producing strains of Staphylococcus aureus, Escherichia coli, Klebsiella sp., Proteus, Haemophilus influenzae, and Pseudomonas sp. and against anaerobes. ${ }^{25}$

The infection rate in our series was higher in the patient group without prolonged prophylaxis, but the difference was not statistically significant $(p=$ 0.265 ). The rate of sepsis was higher in the prophylaxis group. In a worst-case situation, assuming a relative risk of 1.97 (upper 95\% confidence limit) for infection and a relative risk of 1.17 (upper 95\% confidence limit) for sepsis, a clear benefit of prolonged prophylaxis cannot be found. Pneumonia diagnosed with the use of clinical and radiologic criteria occurred less frequently in the prophylaxis group. The differences were not significant. In patients with pneumonia, gram-positive cocci could be isolated only in the group with vancomycin/ticarcillin prophylaxis, whereas in all remaining patients of both groups the isolates were gram negative. Pneumonia in most patients was diagnosed after 48 hours when ticarcillin was discontinued. With vancomycin alone a reduction of gram-negative respiratory tract infections could not be expected. In patients with clinical sepsis, CNS was the most prevalent organism in both groups, and it could be detected in blood cultures $(n=2)$, on intravascular catheters $(n=2)$, and on IABPs $(n=2)$ in the prophylaxis group. In contrast to the observations of Karp and Dick, ${ }^{24}$ low-dose vancomycin in our series could not reduce colonization of IABP and intravascular catheters with CNS, the main organism vancomycin was directed against. A wound infection occurred in a single patient in both groups with Escherichia coli in the prophylaxis group and CNS in the control group. The rate of wound infection is too low, however, to 
allow us to draw any conclusions. The whole spectrum of isolated organisms did not show a significant difference in either group.

Total mortality was $28 \%$ and was similar in the two groups. Sepsis and multiorgan failure were the only infectious causes of death in three patients of each group.

Antibiotics had to be instituted in more patients of the control group than the prophylaxis group. The difference, however, was small and insignificant $(p=$ 0.08 ). It may partly be due to the fact that the study was unblinded and the threshold for starting antibiotics was lower in the patient group without ongoing prophylaxis. When comparing the number of positive bacteriologic cultures and the number of patients with positive bacteriologic cultures, the two groups did not differ significantly. Additionally, all laboratory data measuring parameters suggesting infection were similar. The mean minimal body temperature was the only parameter that was significantly different and lower in the control group. This difference, however, may be of no clinical significance. Candidiasis is a known complication of broad-spectrum antibiotics, intravascular catheters, and hyperalimentation. ${ }^{26-28}$ In almost every patient in the present series, these three risk factors were present. However, candidiasis was found more often in the control group, but not significantly more often than in the experimental group. Nevertheless, $73 \%$ of all patients with positive Candida cultures had additional antibiotic therapy for 7 to 10 days. As reported by Hillis and coworkers, ${ }^{8}$ candidiasis may become more frequent when the duration of antibiotic administration is prolonged. Vancomycin or ticarcillin did not show any side effects of clinical relevance.

The size of the studied population is small and limits the strength of the conclusions. Estimating the number of patients necessary to reach a solid conclusion, however, seemed too speculative in view of the variability of the incidence of infections in this inhomogeneous and variable high-risk group of patients.

In conclusion, we could demonstrate that an additional and prolonged postoperative period of broad-spectrum prophylaxis with low-dose vancomycin and ticarcillin/clavulanate could not effectively influence infectious outcome in a high-risk group of patients undergoing cardiac operations. Low-dose vancomycin did not reduce the rate of infections or the colonization of intravascular catheters with gram-positive organisms.
We acknowledge the assistance of Burkhardt Seifert (statistical consultant) in manuscript preparation.

\section{REFERENCES}

1. Geraci JE, Dale AJ, McGoon DC. Bacterial endocarditis and endarteritis following cardiac operations. Wis Med J 1963; 62:302-15.

2. Kreter B, Woods M. Antibiotic prophylaxis for cardiothoracic operations. J Thorac Cardiovasc Surg 1992;104:590-9.

3. Goodman J, Schaffner W, Collins H, Battersby E, Koenig M Infection after cardiovascular surgery. N Engl J Med 1968; 278:117-23.

4. Fekety F, Cluff L, Sabiston D, Seidl L, Smith J, Thoburn R. A study of antibiotic prophylaxis in cardiac surgery. J Thorac Cardiovasc Surg 1969;57:757-63.

5. Fong I, Baker C, McKee D. The value of prophylactic antibiotics in aorta-coronary bypass operations. J Thorac Cardiovase Surg 1979;78:908-13.

6. Conte JE, Cohen SN, Roe BB, Elashoff RM. Antibiotic prophylaxis and cardiac surgery. Ann Intern Med 1972;76: 943-9.

7. Goldmann DA, Hopkins CC, Karchmer AW, Abel RM, McEnany MT, Akins C, et al. Cephalothin prophylaxis in cardiac valve surgery: a prospective, double-blind comparison of two-day and six-day regimens. J Thorac Cardiovasc Surg 1977;73:470-9.

8. Hillis DJ, Rosenfeldt FL, Spicer WJ, Stirling GR. Antibiotic prophylaxis for coronary bypass grafting: comparison of a five-day and a two-day course. J Thorac Cardiovasc Surg 1983;86:217-21.

9. Austin TW, Coles JC, McKechnie P, Sandoval W, Doctor A. Cephalothin prophylaxis and valve replacement. Ann Thorac Surg 1977;23:333-6.

10. Garner JS, Jarvis WR, Emori TG, Horan TC, Hughes JM. CDC definitions for nosocomial infections, 1988. Am J Infect Control 1988;16:128-40.

11. Maki DG, Weise CE, Sarafin HW. A semiquantitative culture method for identifying intravenous-catheter-related infection. N Engl J Med 1977;296:1305-9.

12. Edmunds LH, Clark RE, Cohn LH, Miller DC, Weisel RD. Guidelines for reporting morbidity and mortality after cardiac valvular operations. J Thorac Cardiovasc Surg 1988;96: 351-3.

13. Dean AG, Dean JA, Burton AH, Dicker RC. Epi Info, Version 5: a word processing, database, and statistics program for epidemiology on microcomputers. Stone Mountain (GA): USD Incorporated; 1990.

14. Malanoski GJ, Samore MH, Pefanis A, Karchmer AW. Staphylococcus aureus catheter-associated bacteremia. Arch Intern Med 1995;155:1161-6.

15. Martin MA, Pfaller MA, Wenzel RP. Coagulase-negative staphylococcal bacteremia: mortality and hospital stay. Ann Intern Med 1989;110:9-16.

16. Ponce DeLeon S, Wenzel RP. Hospital accquired bloodstream infections with Staph. ep. Am J Med 1984;77:639-44.

17. Pittet D, Wenzel RP. Nosocomial bloodstream infections: secular trends in rates, mortality, and contribution to total hospital deaths. Arch Intern Med 1995;155:1177-84.

18. Ingerman MJ, Santoro J. Vancomycin: a new old agent. Infect Dis Clin North Am 1989;3:641-51.

19. Sande MA, Scheld WM. Combination therapy of bacterial endocarditis. Ann Intern Med 1980;92:390-5. 
20. Hermans PE, Wilhelm MP. Vancomycin. Mayo Clin Proc 1987;62:901-5.

21. Wüst $\mathrm{J}$, Kayser FH. Dịe Empfindlichkeit von Bakterien gegen Chemotherapeutika (Zürich 1993). Praxis 1995;84:98105.

22. Romanelli VA, Howie MB, Myerowitz PD, Zvara DA, Rezaei A, Jackman DL. Intraoperative and postoperative effects of vancomycin administration in cardiac surgery patients: a prospective, double-blind, randomized trial. Crit Care Med 19993;21:1124-31.

23. Levy $\mathrm{JH}$, Marty AT. Vancomycin and adverse drug reactions. Crit Care Med 1993;21:1107-8.

24. Karp JE, Dick JD. Emergence of gram-positive infections: relationship to indwelling catheters and management during chemotherapy-induced aplasia. Rec Res Cancer Res 1993; 132:221-9.
25. Bush LM, Calmon J, Johnson CC. Newer penicillins and beta-lactamase inhibiotors. Infect Dis Clin North Am 1989; 3:571-94.

26. Gundry SR, Borkon AM, McIntosh CL, Morrow AG. Candida esophagitis following cardiac operation and short-term antibiotic prophylaxis. J Thorac Cardiovasc Surg 1980;80: $661-8$.

27. Edwards JE Jr. Candida species. In: Mandell GL, Douglas RG Jr, Bennett JE, editors. Principles and practice of infectious diseases. 3rd ed. New York: Churchill Livingstone; 1990. p. 1943.

28. Crislip MA, Edwards JE Jr. Candidiasis. Infect Dis Clin North Am 1989;3:103-33. 